\title{
Examining barriers and opportunities for sustainable adaptation to climate change in Interior Alaska
}

\author{
Shannon M. McNeeley
}

Received: 11 August 2010 / Accepted: 1 July 2011 /Published online: 22 July 2011

(C) The Author(s) 2011. This article is published with open access at Springerlink.com

\begin{abstract}
Human adaptation to climate change is comprised of "adjustments" in response to (or anticipation of) climatic impacts. Adaptation does not necessarily imply favorable or equitable change, nor does it automatically imply sustainable use of ecosystems. "Sustainable adaptation" in this case implies strategic, collective action to respond to or anticipate harmful climate change to reduce disruption to key resource flows and adverse effects on general well-being. This research examined social-ecological system responses to recent warming trends in the remote northwest region of Interior Alaska using a unique vulnerability and adaptive capacity assessment (VA) approach that integrated indigenous observations and understanding of climate (IC) with western social and natural sciences. The study found that Alaska Native communities that were historically highly mobile and flexible across the landscape for subsistence hunting are increasingly restricted by the institutional rigidity of the regulatory system for wildlife and subsistence management. This has resulted in negative impacts to game harvest access and success threatening food security and community well-being. This suggests that policies limiting the ability of natural resource-dependent societies to be flexible, diversify, or innovate can threaten livelihoods and exacerbate vulnerability. Nevertheless, opportunities for sustainable adaptation exist where wildlife management is adaptive and includes an understanding of and response to climate variability and slow-onset climate change with the human dimensions of subsistence hunting for more effective "in-season" management.
\end{abstract}

\section{Introduction}

In Interior Alaska, one of the fastest warming places on Earth, the seasons are changing. Recent warmer decades mean the winters are growing longer and milder with less extreme

Electronic supplementary material The online version of this article (doi:10.1007/s10584-011-0158-x) contains supplementary material, which is available to authorized users.

S. M. McNeeley $(\bowtie)$

Advanced Study Program/Integrated Science Program/Research Applications Laboratory,

National Center for Atmospheric Research, PO Box 3000, Boulder, CO 80307, USA

e-mail: smcneele@ucar.edu

S. M. McNeeley

Department of Anthropology and IGERT Resilience and Adaptation Program,

University of Alaska Fairbanks, Fairbanks, AK, USA 
cold temperatures. Spring, summer, and fall have also warmed with seasonal changes observed and felt by the Alaska Natives who live in the region, and who are life-long, astute observers of weather, climate and ecological dynamics. Fall seasonality change, in particular, results in social-ecological system changes when warmer late August and September conditions impact moose behavior and moose hunter harvest success. Moose provide vital winter food security more than any other subsistence or store bought food in the remote, rural areas of Interior Alaska, otherwise known as "The Bush." In order to adapt to climate change-caused seasonality shifts, the Koyukon Athabascan bush communities and their hunters require flexibility across both time and space. Without this flexibility to adapt to a changing environment, food insecurity can result causing great stress to community well-being. Flexibility in physical space and time is critical, but perhaps even more important is the ability to move within policy and political space. The complex dual state and federal regulatory system for subsistence and wildlife management in Alaska contextualizes this space and constrains maneuverability for Alaska Native communities to operate. This happens through policies and regulations that squeeze the window of opportunity for harvest, and when combined with shifting seasonality can be detrimental to rural subsistence communities. This "closing window" forces villagers to choose between complying with regulations, thereby risking food insecurity, or illegal subsistence hunting (McNeeley 2009; McNeeley and Shulski 2011).

This case study demonstrates how the complexity and rigidity of the dual state and federal management system for land tenure and its ecosystem services (i.e., to provide food) for rural villages creates barriers to adaptation to climate change and seasonality shifts. Participation in this complicated regulatory system is mandatory for rural, Alaska Native communities today, forcing them to respond within an imposed framework. Alaska Natives continue to contest this forced adaptation in the ongoing attempt to maintain their rights to land and wild food. However, they are bound by the rule of law, so this paper examines the opportunities and constraints within the system for collective, and perhaps even strategic and sustainable adaptation to climate change.

\section{Sustainable adaptation to climate change}

Adaptation to climate change in human societies entails responding to climate stimuli not just after the fact, but anticipating and planning for potential changes (Smit et al. 2000), especially where early warning signs are present (Glantz 1988). It includes purposeful action in order to avoid the negative consequences of a societies' own actions; it requires the examination and questioning of the status quo for necessary change (Bennett 2005). Adaptation in this case refers to a fundamental, systemic change in response to environmental conditions, change through adjustment that maintains or strengthens the viability of the system (Smithers and Smit 1997). Adaptation of human societies to climate change requires the proper functioning of social, ecological and institutional systems and includes a range of human activities that enhance well-being or quality of life.

Adaptive capacity is thus embodied in the resources that maintain livelihoods (i.e., "livelihood assets") and comes from material and social goods or capital in the form of natural capital (i.e., ecosystem services), social-political capital, human capital, physical capital, and financial capital (IISD et al. 2003). Sustainable adaptation implies a broader mindfulness about the linkages between livelihoods (usually framed as poverty) and climate change and necessitates treating issues of poverty/income, environment, climate change as linked in a system of interacting causes and effects (Eriksen and O'Brien 2007; Bardsley and Rogers 2011; O’Brien and Leichenko 2008). For natural resource dependant people this 
is predicated on the ability to maintain ecosystem services upon which they depend for food security (Ford 2009; Thomas and Twyman 2005; CHINAGRO 2005). This has long depended on flexibility across time and space to account for environmental change and variability. It also depends on access to the resources in the right time and space. Vulnerability and poverty are often addressed through different institutional mechanisms yet it is both necessary and possible to identify those areas of overlap between vulnerability and poverty to target for sustainable adaptation measures (Eriksen and O'Brien 2007).

Social capital describes the relationships and social networks, agreements, flows of information and other aspects of social organization such as trust, obligations and expectations and cultural norms that facilitate coordinated actions to achieve social benefits and facilitate well-being and security (Adger 2003; Dasgupta and Serageldin 2000; Fukuyama 2003; Coleman 1988). It is a societies' ability to act collectively that allows it to utilize its inherent capacity to adapt to climate change (Adger et al. 2004). A closely related concept is institutional capacity, which is the ability of institutions to build capacity, to buffer risk, and to facilitate planning more effectively for necessary change. The more conventional "institutional view" of social capital used by Ostrom and others (Ostrom and Ahn 2003) argues that the capacity of social groups to act on their collective interest depends on the formal institutions under which they reside. This view holds true, in part, but for marginalized communities such as indigenous communities in the Arctic and Subarctic adaptive capacity often exists internally and informally in the form of the knowledge, customs, and practices with effective transmission across generations. Yet, in a rapidly changing environmental and social milieu, including severed ties to traditional knowledge, this capacity is eroded or transformed.

Adaptive capacity is constrained by factors that restricts peoples' ability to have a reservoir of options from which to choose when environmental conditions change (Berkes and Folke 1998; Gunderson and Holling 2002). Adaptive mechanisms (such as food and resource sharing or changing of hunting patterns and practices) operating at the communitylevel are often constrained by institutional hierarchies determining in part how adaptation to climate change manifests through the policy processes (Adger and Kelly 1999). Institutional responses to climate change are often best suited for mitigation of emergency situations and isolated events rather than to slower onset, cumulative or systemic climaterelated problems leading to disruption of ecosystem services; the institutional and regulatory entities are even less well-suited to working with underlying social factors that structure vulnerability (Handmer et al. 1999). Where institutional rule making occurs in a compartmentalized and fragmented framework, responses to climate change have been either nonexistent in the worst case, case-based mitigation in the best.

The need to identify public policies, regulatory measures, and institutional arrangements that impede flexibility of options remove such impediments is a critical piece of building adaptive capacity (Smithers and Smit 1997). In societies where natural resource harvesting is still central to livelihoods, larger-scale policies and institutions oftentimes either exacerbate vulnerability or undermine adaptive responses to harmful change (Thomas and Twyman 2005). Flexibility requires having options, the ability to diversify, to innovate, and the ability to take advantage of those different options moving both in physical space and economic and political space without constraints of the regulatory system (Holling 1978; Lee 1999; Thomas and Twyman 2005). In the case of Arctic and Subarctic indigenous people, harvesting is opportunistic and depends on the ability to make improvised changes in strategies, as well as to make substitutions when certain resources are scarce or unavailable (Ford et al. 2006; Nuttall 2005). Subsistence hunting requires great flexibility to harvest what is available in variable time and space, and the ability to make adjustments when necessary to take advantage of game availability given local seasonal conditions 
(Ford et al. 2007). When hunting regulations restrict this flexibility, harvest success is affected, and frustration, conflict with government officials, agency managers, and/or "outsiders" who encroach on subsistence resources inevitably arises (Nadasdy 2003). This type of conflict inherently hinders the ability to engender the types of collaborative efforts required to develop sustainable adaptation measures.

Social maladaptation occurs when internal factors of the social structure prevent appropriate, adaptive responses in the face of perturbations to the social-ecological system (Rappaport 1978). This is often a result of social complexity that inherently gives rise to institutional complexity with myriad, conflicting interests that lead to gridlock in sustainable, collective action (Bennett 1996). For example, problems arise when highlevel decision makers with the most power are disconnected from the local cultural and environmental context and lack understanding about the changes that underpin the productivity and vitality of a social-ecological system (Redman 1999). This is true in Alaska where there is a chasm between policy makers in Juneau, Anchorage, Fairbanks, and Washington D.C. and those who live in the remote, rural communities off the road system, communities with comparatively little infrastructure and relatively little political influence. This tension between urban centers of power and rural livelihoods persists in Alaska and is central to issues of sustainability for Alaska Natives who choose to live in their ancestral lands. As societies and their institutions become more complex and fragmented with respect to wealth distribution and social inequities, common problems occur in decision making. These problems include, but are not limited to, the inability to detect deviations in variables from mean climate conditions, disconnects in feedback loops of knowledge, distortion of information between decision maker channels, and misunderstanding of information (Redman 1999; Rappaport 1978).

The power and authority to make decisions in complex societies typically usurp what were formerly local decisions and differing viewpoints about risk, rewards, and priorities, a situation that often lead to decisions with disastrous effects on local resilience (Redman et al. 2004). In wildlife management agencies such as the Alaska Department of Fish and Game and the U.S. Fish and Wildlife Service, biological paradigms and political and government agency priorities invariably dominate over local considerations (Wheeler 1992). Consequently, decision makers are often disadvantaged in devising responsible solutions to complex problems such as climate change in a complicated, cross-cultural setting such as the one presented here. Decision makers lack comprehensive understanding about how fundamental social relationships and processes provide community stability, or about how their decisions create unintended consequences for system dynamics in surprising and sometimes negative ways. This dynamic can produce inefficiencies and feedbacks that result in maladaptation and diminishing community resilience over time (Rappaport 1978). This case demonstrates how rural Alaskan communities are impacted by a regulatory decision-making process that, to date, can't effectively respond to slow-onset climate change that impacts moose behavior and moose harvest success thereby threatening food security and community well-being.

\section{Case study: Koyukon Athabascans and fall moose hunt}

The Koyukuk-Middle Yukon (KMY) region of west-central Alaska exhibits a subarctic, continental climate with typical characteristics of long, cold winters, short but relatively warm summers, and light and irregular precipitation coming mostly in the form of rain during the summer. The time series of mean annual temperature exhibit the clear pattern of predominantly below-normal temperatures until 1976, but since this time show 
warmer than average annual temperatures. A clear step-wise shift occurred in the mid1970's, which correlates strongly to the Pacific Decadal Oscillation climate regime change in the Pacific basin (Hartmann and Wendler 2005). The total change of mean annual temperature for the region is $+2.1^{\circ} \mathrm{C}\left(+3.8^{\circ} \mathrm{F}\right)$ from 1944 to 2007 . It is evident that this trend is dominated by strong changes in temperature during the winter (Dec, Jan, Feb) and spring (Mar, Apr, May) seasons, with a total change in seasonal temperatures of $+3.6^{\circ} \mathrm{C}\left(+6.5^{\circ} \mathrm{F}\right)$ and $+2.5^{\circ} \mathrm{C}\left(+4.5^{\circ} \mathrm{F}\right)$, respectively. The summer (Jun, Jul, Aug) and autumn (Sep, Oct, Nov) seasons also show warming, though lower in magnitude, of $+1.4^{\circ} \mathrm{C}$ $\left(+2.5^{\circ} \mathrm{F}\right)$ and $+.89^{\circ} \mathrm{C}\left(+1.6^{\circ} \mathrm{F}\right)$, respectively.

A predominant feature of the cold season in particular is the exceptionally high interannual variability, which is typical of a high-latitude continental climate location (Shulski and Wendler 2007). An indicator of this is the magnitude of the standard deviations for the various seasons: $3.2^{\circ} \mathrm{C}\left(5.8^{\circ} \mathrm{F}\right), 2.3^{\circ} \mathrm{C}\left(4.1^{\circ} \mathrm{F}\right), 1.1^{\circ} \mathrm{C}\left(2.0^{\circ} \mathrm{F}\right)$, and $2^{\circ} \mathrm{C}\left(3.6^{\circ} \mathrm{F}\right)$ for winter, spring, summer, and autumn, respectively (McNeeley and Shulski 2011).

Along with high climate variability is a highly variable and uncertain environment where resource abundance can fluctuate significantly seasonal and annually. The valleys and flatlands of the Koyukuk-Middle Yukon region of the Interior are comprised of wetlands that provide excellent habitat for waterfowl, fish, and water mammals such as beavers and muskrats. Forests are mostly spruce, willow, and birch trees, where moose, bears, and wolves roam. The uplands of tundra and mountain ranges are where the caribou herds pass by seasonally on their annual migrations.

Small, remote, rural villages in the region are still populated with mostly Koyukon Athabascans and a minority of Iñupiaq Eskimos and non-Alaska Natives. The villages in the KMY are entirely off the road system, accessible only by airplane or by boat along the major rivers with mail, fuel, food, and other supplies either flown by daily bush airlines or brought in by barge when the rivers are free of ice. Inter-village regional travel in the winter is by snow machine on winter trails and rivers that become ice roads. Transportation for hunting, fishing, trapping, or gathering is by boat or snow machine, though cars and ATVs are used locally for short trips. The village populations are small ranging from 28 people in Alatna to 580 people in the "hub" village of Galena.

Subsistence on wild fish and game is the central element of the local cash-subsistence economy. Dependence on wild foods is high providing about $57 \%$ of the total calories and $396 \%$ of required protein needs compared to around $2 \%$ of caloric needs $/ 15 \%$ of the protein in urban areas such as Fairbanks and Anchorage (Wolfe 2000). Moose is the most important big game animal harvested in the Koyukuk-Middle Yukon region where $92 \%$ of the households consume moose (Nelson 1983; Brown et al. 2004). Almost all households report using moose even if they didn't harvest themselves, confirming not only the critical importance of moose, but also that sharing and food distribution continues to be important in these communities (ibid). Moose only arrived to Koyukuk River valley within the last 70 years, yet the Koyukon communities are economically and psychologically attached to moose, which have become invaluable to the culture (Nelson et al. 1982). Maintaining a healthy moose population and hunting access are top priorities in the region. Moose are the most efficient of all the wild foods harvested in the region when measured by pounds of meat harvested per unit of time, energy, and money put into the harvest effort (Feit 1987).

Recent warming trends have affected the critical moose hunt by shifting the early fall season later. From 1995 to 2007 there were a predominance of positive anomalies for the fall hunting season (McNeeley and Shulski 2011). However, it wasn't until the period from 2005 to 2007 that the area saw the warmest three-year stretch on record, which exceeded the $1.6^{\circ} \mathrm{C}\left(2.9^{\circ} \mathrm{F}\right)$ temperature standard deviation so were not within the 
expected range of variability. Warmer temperatures cause the moose to start "moving" later, meaning they take longer to move from their summer areas to the fall and winter areas where hunters encounter them for harvesting (McNeeley 2009). This creates a "closing window" for hunters and harvest success because the timing of bull movements determines when and where they can be encountered on the landscape (McNeeley and Shulski 2011). When fall seasonality shifts later, yet the regulatory window for legal harvest remains the same, hunters cannot legally take moose when the conditions allow. One hunting trip can cost as much as $\$ 1,000$ per boat for gas, food, and supplies, making each trip a huge financial risk. Village hunters face two risks they must decide between. One choice is to harvest no moose thereby threatening the food security of their families and communities. The second choice is noncompliance of the regulations, i.e., illegal harvest, which could result in major fines along with revocation of hunting equipment and licenses. This also threatens community food security in the future. In other words, the fall seasonality shift leaves hunters and communities vulnerable, not because of the environmental changes alone, but in the context of the regulatory system that constrains them.

\subsection{The dual state-federal wildlife and subsistence management system}

Following Alaska statehood in 1959, a complicated dual Alaska state and U.S. federal management system for wildlife and subsistence emerged from the Alaska Native Claims Settlement Act (ANCSA) of 1971, and the Alaska National Interest Lands Conservation Act (ANILCA) of 1980. Alaska Natives who were historically highly mobile and flexible across the landscape for their subsistence hunting, fishing, trapping, and gathering became increasingly restricted across both time and space by the institutional morass of rules and restrictions imposed by the state of Alaska and the federal government. Other drivers that led to a more sedentary people over the last century included the Christian missions, trading posts, and legally mandated schools in villages, to name a few (Schneider 1986). However, it was ANCSA and ANILCA that legally restricted movement across time and space when it came to subsistence hunting practices.

The Alaska Native Claims Settlement Act left a legacy of patchwork land ownership and management authority across Alaska that largely defines how the institution of wildlife and subsistence management has developed. In the KMY region there are three national wildlife refuges managed by the U.S. Fish and Wildlife Service office in Galena- the Koyukuk National Wildlife Refuge, the Nowitna National Wildlife Refuge, and the Northern Innoko National Wildlife Refuge (Fig. 1) - and a fourth - the Kanuti National Wildlife Refuge (not pictured) near the more northern villages of Allakaket and Alatna, which is managed in Fairbanks.

Within the three refuge boundaries the federal government is the biggest land owner with $6,044,478$ acres of land, Doyon, Limited regional native corporation is second, with title to 756,839 acres. The state of Alaska, village corporations, and native allotments make up the remaining acres (Fig. 2). Most of the lands surrounding the refuges are owned by the federal government, or managed by the Bureau of Land Management, or are owned by the state of Alaska.

\subsection{Wildlife management authority}

The Alaska state government has primary authority over management of wildlife and subsistence, therefore, the Alaska Board of Game (BOG), made up of seven people appointed by the governor and approved by the legislature, is the central decision making 


\section{Koyukuk, Northern Innoko, and Nowitna National Wildlife Refuges}

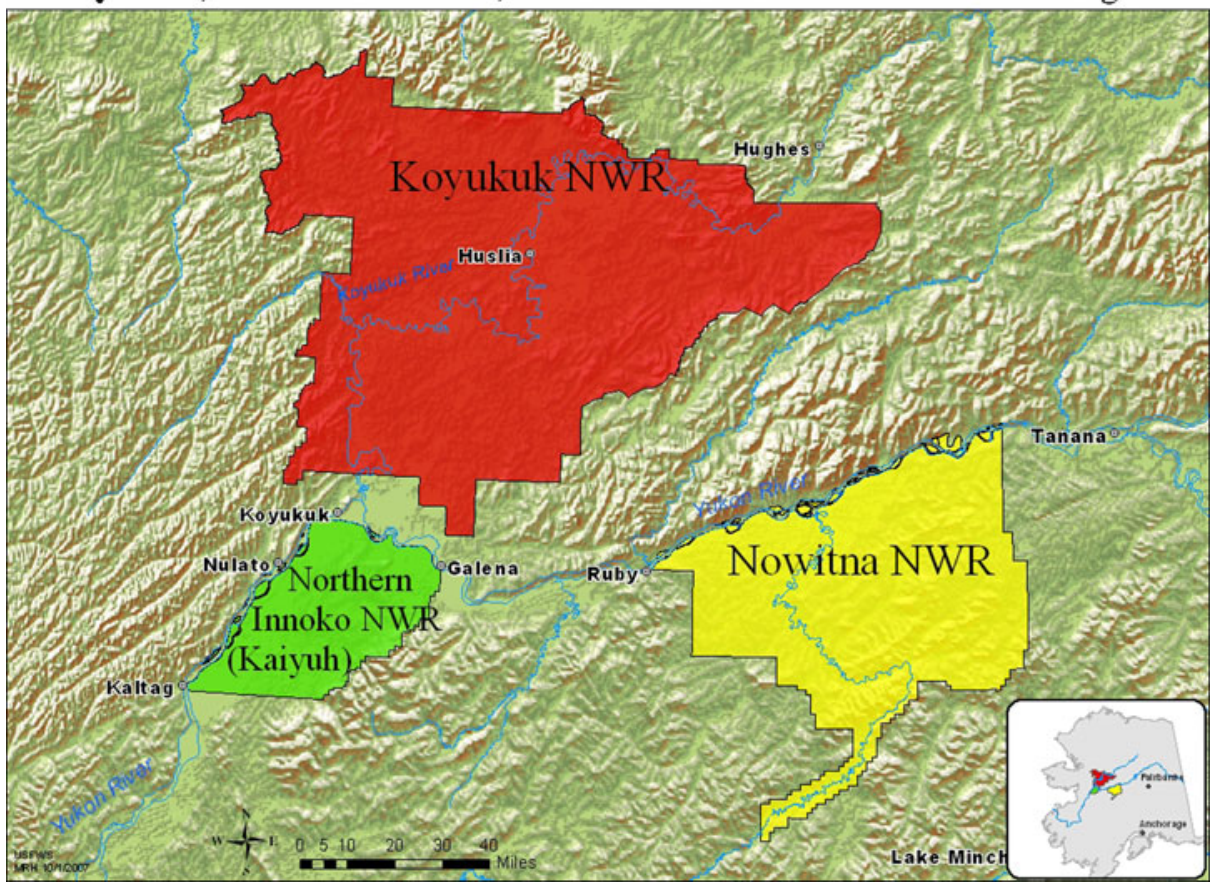

Fig. 1 Map of the Koyukuk, Nowitna, and Northern Innoko National Wildlife Refuges. Map courtesy of USFWS Galena office

body. The composition of the BOG is critical to all decisions made. Rural needs are very different from non-native, urban, and commercial needs in many ways, and the BOG must evaluate the needs of all within a framework that is both legal and constitutional. Given the dominance of commercial interests in natural resource extraction in Alaska (Haycox 2002), the BOG is composed of primarily non-Alaska Natives, and is currently comprised almost entirely of urban males with commercial interests. ${ }^{1}$ Tension between rural subsistence hunters and hunters from urban Alaskan centers, or from those outside Alaska, has been problematic since statehood (1959), which increased since the passage of ANCSA in 1971. There is probably no other forum where this is demonstrated more strongly than in the highly politicized Board of Game meetings where all the stakeholders negotiate the regulations that determine hunting access and rights.

The Alaska Department of Fish and Game (ADF\&G) answers to the BOG and to elected officials, and manages various regions of the state as Game Management Units (GMUs). GMUs $21 \mathrm{D}$ and 24 are the units within the KMY region and cover roughly 38,000 square miles. The ADF\&G Division of Wildlife Conservation manages the wildlife populations along with subsistence according to the regulations determined by the BOG.

The federal government is the largest land owner in the region and plays a very important role in the management of wildlife and subsistence, though largely secondary to the state authority. In an effort to address the complexity of the dual management system, there is an ongoing goal of cooperation and "alignment" between state and federal policies

\footnotetext{
${ }^{1}$ As of this analysis in 2009 only one Alaska Native and no women sat on the BOG.
} 
Fig. 2 Maps of land ownership in the Koyukuk, Nowitna, and Northern Innoko National Wildlife Refuges. Courtesy of the U.S. Fish and Wildlife Service Galena office
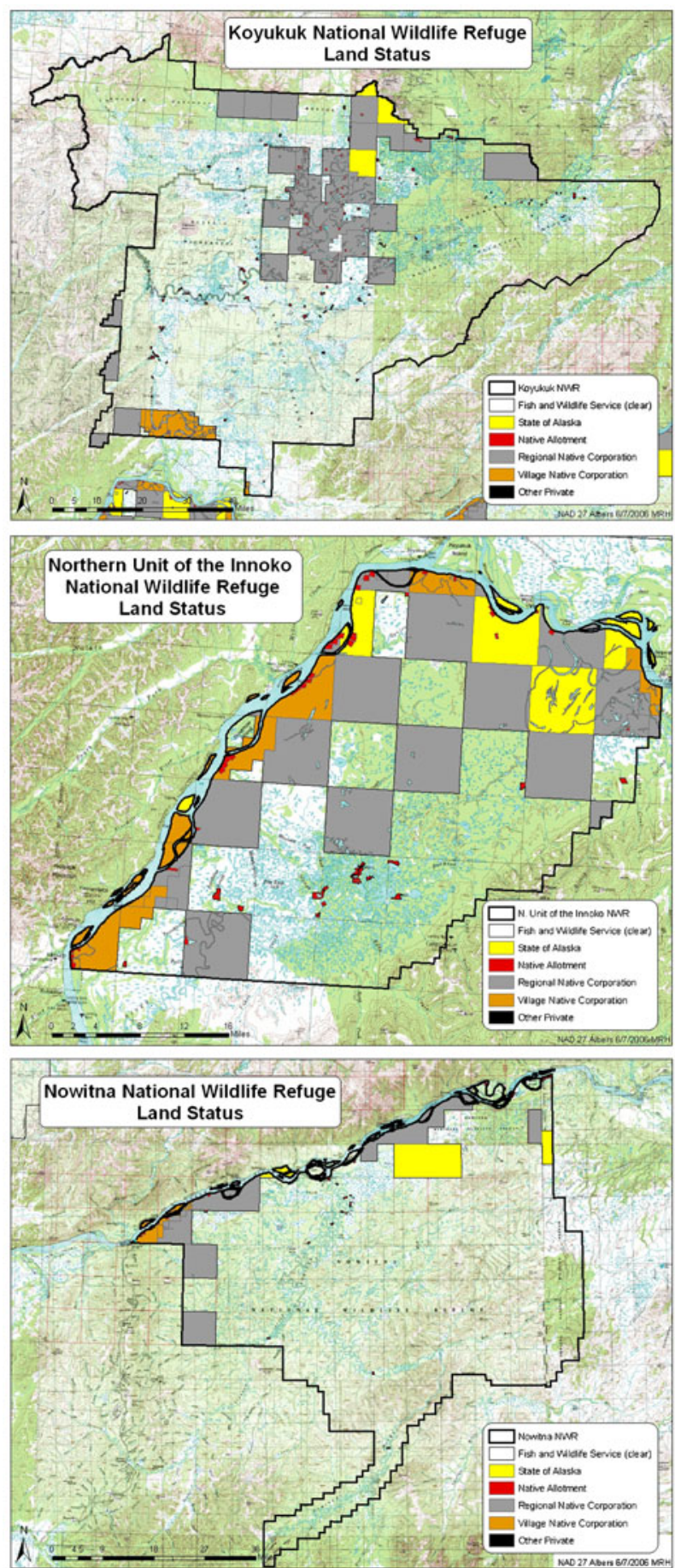
and regulations. State regulations for moose hunting apply on all state, private, and federal lands, with the exception of when there is a resource shortage and federal agencies may authorize additional subsistence harvest opportunities for local, rural residents, with authority for this applying only on federal lands, and only if it is determined on the basis of "scientifically acceptable" evidence that there is a shortage of harvestable moose. The issue of "rural priority" for hunting regulations (per ANILCA Title VIII) in Alaska continues to be the source of conflict for wildlife and subsistence managers across the state.

The decision making body for wildlife and subsistence policies on federal lands is the Federal Subsistence Board (FSB) supported by the Office of Subsistence Management (OSM), another federal agency. The FSB structure and process for public input is similar to the state system in that they have regional citizen advisory councils (in this region it is the Western Interior Regional Advisory Council or WIRAC) and proposals for wildlife regulations are made every other year to the FSB. ${ }^{2}$ The FSB is comprised of the regional directors from each of the five federal agencies, ${ }^{3}$ with the sixth a member from the public appointed as chair.

All of the stakeholders including subsistence and sport hunters, rural and urban residents, state and federal managers and decision making bodies have to operate together within the very complicated dual management system (Fig. 3).

As major landowners in the region, the regional Alaska Native corporation, Doyon, Ltd., has a small advantage in defining hunting access on their lands. As private landowners they may legally limit hunting on native lands to native shareholders only, and may prohibit sport hunting and/or access by individuals from outside the region. Since Doyon, Ltd. is a state-chartered private (for profit) entity, this means that all Alaska Native corporate-owned lands are still governed by the state, including wildlife and subsistence law and implementing regulations. Village corporations were allocated a much smaller percentage of land and money than were the regional corporations through ANCSA, so in general they have less immediate influence (even though the managed resources are literally in their backyards). Village tribal councils and the agency advisory committees prioritize subsistence, but they have no direct authority over management of fish, wildlife and other natural resources. The ADF\&G and the US Fish and Wildlife Service have differing mandates, but they both prioritize fish and wildlife protection above subsistence, which lays the foundation for the regulatory system that binds Alaska Natives and their subsistence practices.

\subsection{The regulatory context - the Koyukuk River Moose Management Plan (KRMMP)}

After a growth in the KMY moose population during the 1980s and early 1990s, it declined in the late 1990s concurrent with an increase in hunting pressure (U.S. Fish and Wildlife Service and U. S. Bureau of Land Management 2005). In 1999, the number of hunters $(N=731)$ and moose harvested $(N=367)$ more than doubled since 1988 (Alaska Department of Fish and Game 2001). This happened in concert with a crash in salmon runs of the late 1990s, putting more pressure on local subsistence moose hunters and the resource to ensure regional food security.

Growing concern among the KMY region communities and state and federal agency representatives resulted in establishment of the Koyukuk River Moose Hunters' Working Group (KMWG) organized by the ADF\&G Division of Wildlife Conservation and comprised of representatives from state fish and game advisory committee members, as

\footnotetext{
${ }^{2}$ The FSB changed from an annual cycle to a two-year regulatory cycle in 2008.

${ }^{3}$ US Fish and Wildlife Service, Bureau of Land management, US Forest Service, National Park Service, and Bureau of Indian Affairs.
} 


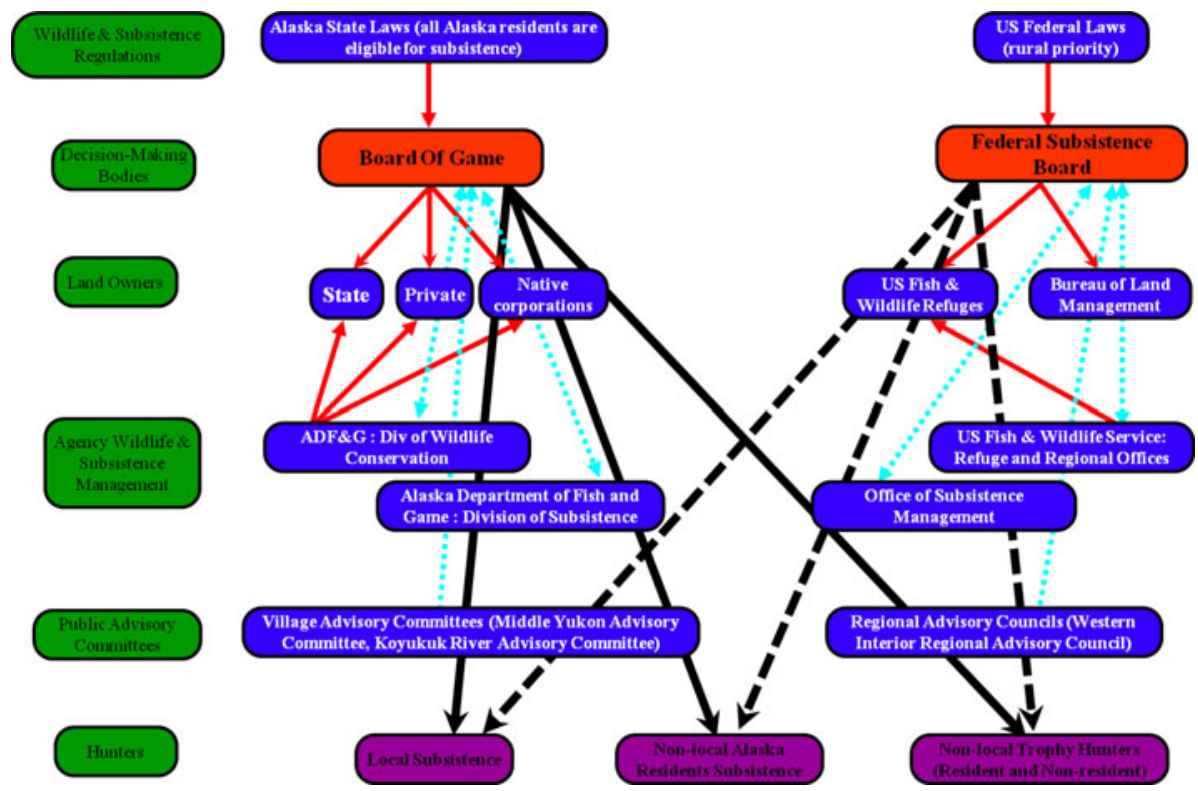

Fig. 3 The complex dual management system for wildlife and subsistence. Arrows with solid lines indicate decision making authority and with dash lines indicate either secondary decision making authority (long dash) or advisory role (short dash)

well as by representatives from the federal advisory committee and commercial operators. With state and federal agency representatives as technical advisors, the KMWG met multiple times over two years (1999-2000) to devise the Koyukuk River Moose Management Plan (KRMMP). Decision making was consensus-based, so all aspects of the plan had to be approved by vote before adoption. The finalized plan was presented to the Board of Game in March 2000 and was approved with only minor adjustments. Therefore, the 2000 fall hunt was the first hunt after implementation of the plan. The KRMMP was not formally a co-management effort since this would imply that villages were given some decision making and management authority shared with the federal and state agencies. The Working Group operated in an advisory role only to develop the plan, but had no regulatory authority. The KRMMP was legitimized by the consensus decision making process, however, over the course of the implementation of the plan since 2000 conflict over the ADF\&G's interpretation and policy recommendations has caused conflict between the local village and agency stakeholders within the group.

\subsection{Management goals, implementation, and current status of the plan}

The KRMMP included eight goals with various recommendations for objectives and actions under each goal-none capable of accommodating seasonal climatic shifts narrowing the allowable hunting period. The primary goal of the plan to:

Manage Koyukuk River drainage moose on a sustained yield basis to provide both hunting and other enjoyment of wildlife in a manner that complements the wild and remote character of the area and that minimizes disruption of local residents' lifestyles (Alaska Department of Fish and Game 2001). 
The limitation of hunting permits is the primary (but not only) tool in the KRMMP for managing moose populations with the goal of reducing the number of hunters and hunting pressure. In the year 2000, the general registration hunt was changed to a drawing permit system with separate Alaska resident and nonresident pools $(N=320 / 80)$, which has greatly limited the number of sport or "trophy" hunters coming to the area. ${ }^{4}$ Since Alaska law considers subsistence eligibility applicable to all Alaska resident hunters (as opposed to just Alaska Natives and/or rural residents), the plan does not have much impact on nonlocal hunters coming from Alaskan urban areas such as Anchorage and Fairbanks, so the locals' anxiety about too many "outside" (i.e., nonlocal) hunters continues, despite measures to limit trophy hunters. This is a source of ongoing tension and conflict between differing views on who has the right to which natural resources and where (in this case moose in the Koyukuk-Middle Yukon region).

In addition to the need for the ongoing cooperation of the stakeholders to respond to changing moose populations, recent years of warm falls, particularly those from 2005 through 2007, have resulted in a "closing window" on the moose harvest in some years when the window for the right seasonal conditions to hunt moose moves later in the fall, but the regulatory window for legal hunting stays the same (McNeeley and Shulski 2011). The only mention of weather (not climate) in the KRMMP is the very last paragraph on page 36 that states simply:

Periodic weather events are an unpredictable variable that will eventually require change to even the most perfectly designed decision making processes. Severe heavy snowfalls have been known to deplete high-density moose populations. It should not be considered a failure of the KRMMP when drastic fluctuations occur in the population as a result of these unforeseen events.

As a result, the KRMMP plan provides no guidance for dealing with climatic seasonality shifts as experienced in the region. In fact, implementation of the plan had unintended consequences that are now in conflict with proposals to shift the regulatory window in accordance with seasonality shifts.

Since the inception of the Koyukuk River Moose Management Plan, the KMY region went from having a general hunt with only two different registration and two drawing hunts to 14 overlapping registration and drawing permit areas and a multitude of different regulations within sub-regions of GMU sub-units. The complexity and rigidity of the dual management system is a major barrier to adaptation to fall seasonality shifts, especially where collective adaptation requires working within this system. How and why is the system inflexible, and how can it be improved to provide needed room to maneuver to respond to seasonal shifts that impact local indigenous people?

\section{Methods: data gathering and analysis}

This paper discusses one part of a larger Vulnerability and Adaptive Capacity Assessment (VA) fully described in McNeeley 2009 with the vulnerability analysis piece (focusing on climate exposure and community sensitivities) described in McNeeley and Shulski 2011. Here we present the analysis on adaptation within the regulatory system for wildlife and subsistence in Interior Alaska in the KMY region. This analysis entailed observing multiple

\footnotetext{
$\overline{4}$ The subsistence registration hunt remained unlimited within the KCUA and the general hunt in GMUs 21D and 24 outside the KCUA.
} 
state and federal agency management meetings, document analysis of records of decisions and transcripts of previous meetings, timeline creation of decisions related to warmer falls and moose movements, and informal discussions with a multitude of stakeholders including agency managers and biologists as well as local and regional advisory committee members.

The analytical framework and approach of this study was an in-community, placebased, participatory Vulnerability and Adaptive Capacity Assessment (VA) (Smit and Wandel 2006). This approach employs historical data to establish baseline vulnerability and adaptive capacity and ideally contributes to practical adaptation initiatives. VA entails understanding the phenomena and main processes involved in the social-ecological system and identifying relationships and key resources susceptible to harm (e.g., food, financial, or energy resources) (Adger et al. 2004). One of the reasons to incorporate indigenous knowledge into scientific studies is to avoid the ethnocentric predetermination of problems (Sillitoe 1998), which can lead to erroneous interpretations (Cruikshank 1998). This approach followed the model set forth by Smit and Wandel (2006) where problems of and determinants of vulnerability are not determined a priori, but rather determined with the stakeholders themselves. See supplemental reading section for more detail on methods.

\section{Findings}

Food security for the Koyukon communities is predicated on the ability to access the natural resources at the right time and in the right place. It also requires flexibility to move across the landscape when the timing is right in response to environmental changes. This long-held capacity to maneuver in relation to seasonality is increasingly threatened by both climate change and regulatory structures. Slow-onset climate stress resulting in seasonality changes combined with regulatory rigidity restricts this access and flexibility across both time and space. A variety of interacting stressors hinder adaptive capacities of the KMY communities to the fall warming and seasonality changes affecting moose harvest success. The "closing window" resulting from later, warm falls and a relatively fixed fall moose hunting season has challenged the institutional capacity to effectively and efficiently respond to such changes thereby threatening regional food security of the indigenous communities. Here we present three key factors demonstrating this lack of institutional capacity, which include: 1) knowledge gaps about weather and climate, 2) uncertainty about the relationship between climate and moose breeding dates and the rigidity of regulations that preference biological concerns over climate and cultural concerns, and 3) an inefficient lag response in the regulatory process. All of these factors create highly complex and rigid regulatory processes within which state and federal government agency moose conservation concerns and management strategies conflict with local needs.

\subsection{Weather, climate and the shifting regulatory window}

Requests to the Alaska Board of Game (BOG) and the Federal Subsistence Board (FSB) to change the dates of the fall and winter moose hunts in the Interior have been ongoing since the 1990s when poor salmon runs combined with periods of severe weather that limited subsistence activity caused regional food insecurity. In 2001 the first emergency petition to the BOG came from two village Tribal Councils requesting to extend the fall moose hunting season in Unit 21D because of a warm fall and the inability to meet harvest needs [See 
Table 1]. The ADF\&G Division of Wildlife Conservation advised the board against the extension stating:

The vagaries of weather are a constant challenge to hunters and low hunter success should not by itself be considered reason to provide additional hunter opportunity. The area management biologist believes that harvest increased during the last days of September season, and feels that total harvest approached the levels desired.

The BOG denied the petitions because they did not feel that the request met state's the emergency criteria defined as "an unforeseen, unexpected event that either threatens a fish and game resource, or an unforeseen, unexpected resource situation where a biologically allowable resource harvest would be precluded by delayed regulatory action and such delay would be significantly burdensome to the petitioners because the resource would be unavailable in the future." This decision, based on weather variability, not climate change, demonstrates the inability for the emergency petition process to deal with or account for issues of slow-onset climatic changes even though climate change-related phenomena are, in essence, unpredictable.

In 2004 the Federal Subsistence Board's reasoning was similar to the state's 2001 decision, with the request denied because it did not meet the federal criteria for Special Action requests that states:

A change in seasons, methods and means, harvest limits and/or restrictions on harvest only if there are extenuating circumstances necessitating a regulatory change before the next annual proposal cycle. Extenuating circumstances include unusual and significant changes in resource abundance or unusual conditions affecting harvest opportunities that could not reasonably have been anticipated and that potentially could have significant adverse effects on the health of fish and wildlife populations or the subsistence uses.

Table 1 Emergency Petition, Special Action, and Proposal Timeline for Extension of Fall Moose Hunt due to Warmer Falls in the Koyukuk-Middle Yukon Region of Interior Alaska

\begin{tabular}{|c|c|c|c|c|}
\hline Year & $\begin{array}{l}\text { State }(\mathrm{BOG}) \text { or } \\
\text { Federal (FSB) }\end{array}$ & $\begin{array}{l}\text { ER Petition (EP), Special Action } \\
(\mathrm{SA}) \text { or Proposal }(\mathrm{P})\end{array}$ & Proposed by & Decision \\
\hline 2001 & BOG & $\begin{array}{l}\text { EP to extend fall hunting season in } \\
\text { unit } 21 \mathrm{D}\end{array}$ & $\begin{array}{l}\text { Kaltag and Nulato tribal } \\
\text { councils }\end{array}$ & Denied \\
\hline 2004 & BOG & $\begin{array}{l}\text { EP to extend all hunting season in } \\
\text { unit } 24 \mathrm{~B}\end{array}$ & Allakkaket tribal council & Denied \\
\hline 2004 & FSB & $\begin{array}{l}\text { SA to extend hunting season in } \\
\text { Kanuti National Wildlife Refuge }\end{array}$ & Alatna tribal council & Support \\
\hline 2005 & BOG & $\begin{array}{l}\text { EP to extend fall hunting season } \\
\text { near Ruby village }\end{array}$ & Ruby tribal council & No Action \\
\hline 2005 & FSB & $\begin{array}{l}\text { SA to extend fall hunting season in } \\
\text { Nowitna National Wildlife Refuge }\end{array}$ & $\begin{array}{l}\text { Ruby tribal council and } \\
\text { city of Ruby }\end{array}$ & Denied \\
\hline 2006 & BOG & $P$ for fall extension in units 24 and 21 & $\begin{array}{l}\text { Western Interior Region } \\
\text { Advisory Council }\end{array}$ & Failed \\
\hline 2006 & FSB & $\begin{array}{l}\text { P to extend season in Koyukuk } \\
\text { National Wildlife Refuge }\end{array}$ & $\begin{array}{l}\text { Western Interior Region } \\
\text { Advisory Council }\end{array}$ & $\begin{array}{l}\text { Support with } \\
\text { modification }\end{array}$ \\
\hline 2008 & BOG & $\mathrm{P}(\mathrm{N}=5)$ to extend fall hunting season & Multiple parties & $\begin{array}{l}1 \text { Passed } 4 \\
\text { No Action }\end{array}$ \\
\hline
\end{tabular}


The wording of the regulations is such that the FSB could have considered warming falls to be an "unanticipated event." However, the FSB was either unaware of the temperature changes that had occurred, or chose to interpret climate warming as predictable or expected inter-annual weather variability. Climate data analyses show an anomalous stretch of warm years in comparison to the long-term average during the time period of these requests for a change in the regulated moose season. From 1995 to 2007 there were a predominance of positive anomalies (i.e., warming trend) for the fall hunting season (McNeeley and Shulski 2011). However, it wasn't until the period from 2005 to 2007 that the area saw the warmest three-year stretch on record, which exceeded the $1.6^{\circ} \mathrm{C}\left(2.9^{\circ} \mathrm{F}\right)$ temperature standard deviation, so they were not within the expected range of variability as implicitly determined by the boards. Without the analysis of the climate record to inform them, the decision makers were at a disadvantage for knowing their determination was, in fact, erroneous. Between the years 2004 to 2006 multiple similar requests were denied along these lines of reasoning. This demonstrates the difficulty of detecting the difference between inter-annual variability and slow-onset climate change when operating in a knowledge vacuum without the focused statistical analysis combined with local observations, though it was the locals who knew these were unusual conditions. Unfortunately, neither the local stakeholders nor the agency managers had the research capacity or evidence at that time to present to the boards.

\subsection{Uncertainty about climate change and moose}

There are multiple reasons why conflict arises regarding the issue of extending the fall moose hunt because of incomplete information and misunderstanding, differing priorities, elevating scientific knowledge to priority status over indigenous knowledge, and differing interpretations of data. While hunters, biologists, and managers use various types of data and information to make decisions, given the gaps and lack of certainty, judgment calls include personal perceptions and cognitive and cultural models that guide decisions (Plous 1993; March 1994). Agency managers are forced to make difficult decisions today regarding moose populations, harvest data, and breeding dates based on past conditions with limited and often incomplete baseline data. Three areas of knowledge gaps result in competing interpretations of the health and growth of the moose population, harvest success, and the effect of climate change on the moose rut and breeding dates. The first knowledge gap pertains to a discrepancy in opinion between state biologists and managers, federal biologists and managers, and local communities on the moose population trends. The second knowledge gap relates to harvest reporting and whether or not community harvest needs are met. The state biologist interprets data to mean that local communities are getting harvest needs met while local communities say they are not. The third knowledge gap pertains to the relationship between moose populations and climate change. Since here we are focusing on climate considerations, I will discuss the third knowledge gap in this paper and refer readers to McNeeley 2009 for a full description of the other two.

In 2006 the first formal proposal ${ }^{5}$ to extend the fall hunt because of warmer falls came from the Koyukuk-Middle Yukon region to the BOG. The ADF\&G staff recommendation was to "not adopt," citing concerns about the low moose population. The "not adopt" recommendation was supported by the BOG: "the board believes the conservation concerns

\footnotetext{
${ }^{5}$ Formal proposals are submitted to change the regulations, whereas the emergency orders and special actions are just to apply for special extensions during one season. In effect, the proposal changes, if adopted, are more "permanent" or "on the books."
} 
are greater than the need to have a longer hunt" (Alaska Department of Fish and Game 2006; Alaska Board of Game 2006).

By the spring 2008 BOG meeting, the region had experienced 3 successive years of unseasonably warm fall temperatures, with overall departure in the KMY region of $2.2^{\circ} \mathrm{C}$ $\left(4.0^{\circ} \mathrm{F}\right)$ from mean temperatures (McNeeley and Shulski 2011). Five KMY region proposals were presented to the board to shift the hunting season 5 days later from September 20th to September 25th (one of which was to provide a state hunt on native corporations lands to coincide with a federal extension). ${ }^{6}$ A five-day shift would return the season to the dates of the fall hunt before changes were implemented in 2000 per the Koyukuk River Moose Management Plan that had shifted the season dates to August 27th to September 20th.

A simple 2-week summary analysis of temperature data for Interior stations was presented to the board by one of the ADF\&G wildlife biologists (Alaska Department of Fish and Game 2008). ${ }^{7}$ The analysis concluded that there had been a slight statistically significant shift to warmer temperatures during the first week of the hunting season, but not during the second. The board interpreted this as "really no change in the weather" and found it to be an insignificant concern compared to the more important biological concerns for conservation of the moose population in the region. They later reversed their decision on one of the seven proposals to extend the season to September 25th to provide more opportunity in the fall and hopefully alleviate pressure to illegally hunt cows in the winter. However, the decision was made not because they agreed with the observations of a seasonality shift, rather because they prioritized the biological argument for conservation.

The short-term effects of warm weather on moose in the fall time are not disputed. Subsistence hunters and agency biologists have all observed the effect that warm temperatures have on moose, as well as the difficulty of finding and harvesting game, and on preserving the meat (Mowry 2007). It is known that hot temperatures are hard on moose, because they spend more time resting and less foraging (Vucetich and Peterson 2008). What is unknown is whether there might be any long-term effects of climate change on moose, with specific impacts on moose breeding patterns. Wildlife biologists state that moose breeding is triggered only by photoperiod, but indigenous observers question the conventional scientific understanding that warmer falls do not affect the rut in terms of the timing of breeding dates:

A lot of your data includes periods of times where we've had more typical weather where we've had a rut as we see a rut. The rut has been disrupted in recent years because of changes in weather. But your documentation that you use as the reason you don't want to change it is that that hasn't really occurred or shifted that. My perspective is that if you don't have a typical rut they've already shifted on their own. Their breeding season has moved later. They don't just start rutting just because it's the 25th. Their bodies have to get up to a point where they can breed and part of that is what we see "the rut." These animals quit eating, their stomachs are full of water, their necks swell and all of that and that's what gets them ready to breed. They don't just say “okay it's the 25th I'm not ready yet, but I'm going to start breeding because

\footnotetext{
${ }^{6}$ The rationale for the native corporation lands proposals was that it would provide opportunity for native shareholders in the villages and not nonlocal "subsistence" hunters as corporations can exclude nonshareholders from their lands. The incentive for this is that native corporation lands are closer to many (but not all) of the villages so they would not have to travel longer distances to get to federal lands, thereby saving on costs of fuel, etc.

${ }^{7}$ Summarized data was provided by a National Weather Forecaster that examined temperature from 1960 to 2006 for September 1-8 as week one and September 9-15 as week two for Northway, Fairbanks, Tanana, Bettles, Galena, and McGrath.
} 
it's the 25th." The weather has changed. (R.S. Middle Yukon Advisory Committee

Meeting February 13, 2008)

It is very difficult to determine the exact date of breeding under natural conditions, and few studies provide detailed data (Schwartz 1997). Studies on average breeding dates across North America show very little difference across years, suggesting that photoperiod (i.e., hours of daylight), not weather, influence rut timing (ibid). In Alaska, only two studies provide breeding date ranges for moose. Schwartz and Hundertmark (1993) performed a study from 1987 to 1991 on the Kenai Peninsula with captive and road-killed moose, and determined a breeding date range from September 28th to October 12 th, and a mean date of October 5th. The second study commonly cited on moose breeding dates for Interior Alaska was conducted in Denali National Park during 19801991, and through copulation observations estimated a median breeding date of October 2nd and a peak breeding date of October 3rd with a range from September 24th through October 7th (Van Ballenberghe and Miquelle 1993). Despite the limited research, this is the evidence used by ADF\&G biologists to confirm peak breeding dates in the KMY region. This study also concludes that weather plays a minor role given the yearly variation in snowfall and temperature, and the consistency of breeding during a window of 14 days each year.

The problem, again, is that the Van Ballenberghe and Miquelle study accounts for variation in weather rather than changes in climate, and understanding the difference is important because they involve different time scales. Within the ADF\&G Division of Wildlife Conservation, there is widespread acceptance of this range of breeding dates and the conventional wisdom that rut is determined by photoperiod, not weather; "changes in weather" are dismissed as having no possible effect on breeding dates. Climate concerns long-term trends (over several decades or more) and changes in average conditions, for which these studies do not account. Weather, on the other hand, is the state of the atmosphere in a specific time and place with respect to temperature, precipitation, wind, cloud cover, storminess, and barometric pressure. Both of the Alaska studies mentioned here were done in the $1980 \mathrm{~s}$ before the more recent and continued warming trend through the 1990s and 2000s. ${ }^{8}$ No studies have been performed to determine climate effects on breeding dates and it is unlikely that any will happen soon in the $A D F \& G$, given the costs and time required of doing this type of research (pers. comm. Tom Paragi, 2008). Because of the confusion between inter-annual weather variability and climate change, it is questionable whether the evidence available is precise enough to support the claim about static breeding dates under conditions of a changing climate, or even to use these data as the only basis for making management decisions. When management decisions are rigid and have such widespread implications on food security and community well-being, the burden of proof is on the research community to pursue rigorous inquiry into the topic.

While it is certainly plausible that breeding dates have not changed dramatically, local observers have a different perspective, which leads to conflict between locals and agency representatives. There are obviously large gaps in knowledge and understanding for decision making to be made with greater certainty. It is often not possible to fill the gaps in knowledge given budget constraints or simply the difficult nature of certain kinds of studies

\footnotetext{
${ }^{8}$ It is also worth noting that the moose population in the Van Ballenberghe and Miquelle 1993 study is characteristically different than in the KMY as it is an unhunted population tolerable of human presence in Denali National Park that made for a good study population, but might have implications for different rut and breeding behavior and timing.
} 
as mentioned here. It is important for devising appropriate solutions for these very complex problems that where there is uncertainty in the science this must be made explicit.

\subsection{Lag response time for adaptation measures}

At the moment the only "in-season" mechanism to respond to unusual conditions is through the emergency requests. Thus far, most of these requests to address unusually warm fall seasons have been denied (Table 1). This has fueled a cycle of unintended stress and mistrust, which delegitimizes the systems for local stakeholders and breeds more resentment between tribes and agencies, which in turn breeds more incentive for noncompliance with the regulations (i.e., illegal harvests).

The two-year proposal cycles for the Board of Game and the Federal Subsistence Board build in a nonresponsive lag time for implementing changes in the regulatory system. Effective response through this proposal system occurs in hindsight after a climatic disturbance, yet in a climate system with high variability from year to year. "In season" management responsive to seasonal conditions as they are occurring would be more supportive of subsistence hunter success. However, as the system currently operates conditions that change because of inter-annual variability and shifting seasonality have resulted in this back and forth emergency petition and proposal cycle to proposal cycle where regulatory changes happen after the fact, and which may not actually be appropriate for the upcoming seasonal conditions. Climate change is not linear and still will mean significant inter-annual and inter-decadal variability. A more responsive system that is flexible and accounts for high variability will be necessary for sustainable adaptation.

\section{Toward sustainable adaptation solutions}

This case study demonstrates that the interactions between a small, but significant fall seasonality shift, resulting ecological changes and moose behavior, and the regulatory system restrictions on local community significantly impact access to the resource in the right place and time. Local communities in this case need a more flexible, responsive regulatory system that can respond accordingly to environmental changes and inter-annual variability, especially in the warmer-than-normal years. Warm falls are projected to be more common in the future (Walsh 2009). It is imperative to build the institutional capacity to understand and manage for climate-ecological-cultural system dynamics as an integrated whole. Finding ways to rise above the areas of conflict toward a more collective, cooperative relationship among all the stakeholders will be important for sustainably adapting to future climatic and seasonal shifts. Without a recognition of this and concerted effort by all stakeholders to achieve this, collective and sustainable adaptation to climate change could remain a concept instead of a reality. Wildlife management policies hinder adaptation to climate changes when they restrict flexibility, lack understanding of climate and weather knowledge, and that assume shared management goals. However, where these shortcomings of the system can be acknowledged and addressed, sustainable adaptation policies are possible.

The stakeholders in the KMY need to implement collective, strategic action that brings climate change into focus in the context of subsistence and wildlife management. Successful or sustainable adaptation to climate change can be evaluated by strategic actions and their effectiveness (robustness to uncertainty and flexibility), efficiency 
(distribution of costs and benefits, nonmarket values, and timing of adaptation actions), legitimacy (extent to which all stakeholders view decisions as legitimate), and equity (Adger et al. 2005a).

\subsection{Incorporating knowledge of climate variability and change}

Perhaps the most important message regarding fall warming and regional impacts on moose hunting is that warming is not linear, the climate system is highly variable and uncertain, and, while the warming trend is likely to continue according to climate model projections, some years will still be more "normal" or favorable to successful moose harvest, and some will be colder than normal. It is important to recognize both climate variability and climate change when devising solutions, as such avoiding a "preparedness paradox" where adjustments are made to warmer conditions in a rigid fashion, which have unintended consequences or catch people off guard when cool conditions return. In fact, this is exactly what happened in the fall of 2008 when colder conditions prevailed for the first time in many years, and villagers were caught unprepared for winter conditions in time for the late fall freeze (pers comm., Karin Lemkuhl-Bodony 2008). A lack of this type of understanding and knowing how to integrate these considerations into preparing for upcoming harvest seasons as well as planning for subsistence management and policies is one of the multiple barriers to sustainable adaptation.

6.2 Research needs for understanding climate change impacts on moose and moose harvest

\subsubsection{On harvest reporting and subsistence needs}

Focused, un-biased research on harvest reporting would help to reconcile the disconnect between what might look to some like an increase in or steady harvest, but could instead be increased reporting from the past. Conducting household surveys for moose and other big game as those carried out by the ADF\&G Subsistence Division from 1997-2003 are critical for this effort. More attention placed on whether needs are being met as opposed to focusing just on how many moose are harvested would go a long way in helping managers make decisions that both conserve the moose population and help local stakeholders meet their subsistence needs. This would work toward the effort of building social capital through increased trust, communication, and implementation of actions toward shared goals.

Socio-economic research on how meat is distributed within the villages, between villages, and between rural and urban areas would be a step in this direction. This would necessarily include methods to estimate distribution of pounds of meat, not just harvested moose. This would give a more accurate understanding of sharing and distribution patterns of subsistence harvesters in the region and overall food security. Too many assumptions are made on anecdotal evidence such as how much meat is donated by nonlocal, trophy hunters, quantity of meat that leaves the region, or quantity of meat that actually ends up in household freezers. Little to no empirical data exists for these important food security variables.

\subsubsection{On moose and climate}

As the moose population and harvest data become more reliable, in theory, it would be possible to look at the temperature sensitivity more quantitatively. This could be represented by a frequency distribution by analyzing the changes in harvest success per unit of change in temperature similar to the example presented in Luers (2005). By combining as an 
integral the change in harvest multiplied by the temperature and weighted by the frequency of a given temperature, one could arrive at a more quantitative value for sensitivity of the fall moose hunt to warming temperatures. But this would only provide robust results with solid harvest data that were at least a decade if not longer. Currently the harvest data that are available would not provide robust results.

Practical measures for collective adaptation must include not only adequate data and a strengthening or nurturing of communities' cultural adaptive capacity, but also necessitate strategic action for ensuring that the capacity or potential can be realized via adaptive measures that promote rather than hinder adaptation strategies. Two of the most important characteristics defining these communities' adaptive capacity are 1) community sharing practices and patterns combined with 2) flexibility across time and space. Adaptation is going to require a system that enhances, not hinders these characteristics. Through the incorporation of cultural understandings of humanenvironment relationships that include, for example, Koyukon views on hutlaanee (i.e., the proper relationship of humans to all living things), management and regulations would be more inclusive of local perspectives, which would improve the ability to meet management goals. This would include incorporating local ideas about what these views mean not just in terms of conservation outcomes but also for management and regulatory processes. If locals felt their cultural views and practices were respected and incorporated into management this would help build the social capital (relationships, trust, sharing of knowledge) so crucial for cooperative, collective action and planning to adapt to future climate change.

\subsection{Regulatory reform and "in-season" management}

There is a great need for "in-season" management tools so that hunters and managers can take into account the variable changing climatic conditions each year. Currently, managers cannot proactively respond when conditions push the seasonal conditions back later in September, and the only recourse for hunters is to submit an emergency order or special action request to the state and federal game boards, which have been voted down the majority of times (see Table 1). An alternative to the current system could be explored whereby managers work with weather and climate forecasters and subsistence specialists to try to both anticipate and respond to both climate conditions and village harvest success during each season. Starting in August conditions could be monitored through both weather station observations as well as indigenous observations of climate (IC) to assess temperature and precipitation and determine if the season has anomalous conditions that affect moose movement from warm temperatures and/or access to hunting grounds because of a lack of precipitation at the right time resulting in lower water levels. Climate scientists could experiment with managers and hunters by providing seasonal forecasts that could then be "ground truthed" by integrating actual observations made by local stakeholders and weather stations.

In this case, efficiency would be achieved through streamlining the regulatory process, resulting in a reduction in regulatory proposals and emergency orders/special requests to the Board of Game and Federal Subsistence Board to extend the fall moose hunting season. From the agency manager's perspective efficiency would also come in the reduction in noncompliance and illegal harvest to better achieve shared conservation goals. This requires a system with legitimacy that addresses local subsistence needs and acknowledges local community conservation strategies. Equity and legitimacy from the local village perspective are based on ability to successfully harvest and meet subsistence needs of families, 
households, and communities. As long as locals feel they are being constrained by the system, noncompliance (i.e., illegal harvest) will continue defeating management goals.

The Koyukuk River Moose Management Plan still guides management decisions for the KMY. The plan was written for 5 years (2000-2005), yet since the inception of the Management Plan in 2000 there have been substantial state and federal regulatory changes, some changes in the moose population dynamics, climatic changes, and changes in the socio-economic and environmental conditions that warrant updating of the Plan. Yet at the time of this writing no funding or plan exists to continue or renew the planning process to update the KRMMP. A new strategic planning effort is needed to update the Koyukuk River Moose Management Plan to account for how social-ecological and climatological conditions have changed over the last decade. A new planning effort must do better than the KRMMP to integrate issues of climate and culture in order to cultivate and nurture social and institutional capital and build a more responsive, flexible regulatory and management system. This effort should include the ADF\&G Subsistence Division in a leadership role and including climate experts - not just physical scientists but those who study, social-ecological impacts, vulnerability and adaptation and the important social and political issues that currently constrain sustainable adaptation. An improved system for collecting harvest data through a combination of household surveys and harvest tickets would be beneficial, but only insofar as there is some way to reconcile the differences, which would require adequate staff time and funding to support along with the other research and planning efforts here.

A planning effort would focus on not just shared goals but the processes by which to achieve those goals. Inattention to the latter is a source of conflict where interpretation of how best to achieve goals differs. Processual equity is as important, if not more so, than the outcomes as it determines those outcomes through fortifying social capital—a process that is culturally sensitive, inclusive, iterative, and transparent - in how decisions are made (Adger et al. 2005b; Thomas and Twyman 2005). Gaps in knowledge and understanding must be made explicit and transparent.

\section{Conclusion}

In conclusion, continuing to restrict hunter access creates a positive feedback loop that encourages exactly the opposite of conservation goals through noncompliance and illegal harvest. The locals want to be in compliance, but when a system that controls their access restricts ability to feed their families, their cultural practices and needs will take precedence over the written law. By understanding and nurturing the intrinsic adaptive capacity of local communities to use flexible and innovative harvesting measures when needed, more legitimacy of the system will result ultimately leading to more regulatory compliance. Sustainable adaptation will, therefore, require more management flexibility, cooperation, and strategic planning for future climate variability and change particularly in light of the nature of temperature variation and warming in recent falls. It will require ongoing collaboration and communication among the stakeholders as well as continued monitoring and documentation of environmental changes.

Acknowledgements This research was funded by the National Science Foundation through the National Center for Atmospheric Research and the University of Alaska Fairbanks. Thank you to Terry Chapin, Craig Gerlach, Bill Schneider, John Walsh, Peter Schweitzer, Lisa Dilling, Chanda Meek, Hannah Brenkert-Smith, and Josh Foster for their helpful comments. Also, a thanks goes to the Koyukon communities, the U.S. Fish and Wildlife Service who provided research and logistical support, and the Alaska Department of Fish and Game, especially Caroline Brown. 
Open Access This article is distributed under the terms of the Creative Commons Attribution Noncommercial License which permits any noncommercial use, distribution, and reproduction in any medium, provided the original author(s) and source are credited.

\section{References}

Adger WN (2003) Social capital, collective action, and adaptation to climate change. Econ Geogr 79:387404

Adger WN, Kelly PM (1999) Social vulnerability to climate change and the architecture of entitlements. Mitig Adapt Strateg Glob Chang 4:253-266

Adger WN, Brooks N, Bentham G, Agnew M, Eriksen S (2004) New indicators of vulnerability and adaptive capacity, technical report 7. Norwich, England

Adger WN, Arnell NW, Tompkins EL (2005a) Successful adaptation to climate change across scales. Glob Environ Chang 15:77-86

Adger WN, Arnell NW, Tompkins EL (2005b) Successful adaptation to climate change across scales. Glob EnvironChang-Human Policy Dimens 15:77-86

Alaska Board of Game (2006) Summary of Actions for the Interior Region Board of Game Meeting, March 10-21. 14. Fairbanks, Alaska

Alaska Department of Fish and Game (2001) Koyukuk River Moose Management Plan 2000-2005: Unit 24 and the northern portion of 21D. ed. Division of Wildlife Conservation, 37

Alaska Department of Fish and Game (2006) Draft recommendations: board of game proposals March 2006. Division of Wildlife Conservation, Juneau, p 36

Alaska Department of Fish and Game (2008) Staff Report to the Board of Game, March 29, 2008 Document No. RC30. 1-7. Fairbanks, Alaska

Bardsley DK, Rogers GP (2011) Prioritizing engagement for sustainable adaptation to climate change: an example from natural resource management in South Australia. Soc Nat Resour 24:1-17

Bennett JW (1996) Human ecology as human behavior. Transaction Publishers, New Brunswick

Bennett JW (2005) The ecological transition: cultural anthropology and human adaptation. Aldine Transaction, New Brunswick

Berkes F, Folke C (1998) Linking social and ecological systems: management practices and social mechanisms for building resilience. Press Syndicate of the University of Cambridge, Cambridge

Brown CL, Walker R, Vanik SB (2004) The 2002-2003 Harvest of moose, caribou, and bear in middle Yukon and Koyukuk river communities. In: Big game harvest assessment project, 41. Division of Subsistence, Alaska Department of Fish and Game, Juneau, Alaska

CHINAGRO (2005) Policy Decision Support for Sustainable Adaptation of China's Agriculture to Globalization (CHINAGRO), p 146

Coleman JS (1988) Social capital in the creation of human capital. Am J Sociol 94 Supplement:95-120

Cruikshank J (1998) The social life of stories: narrative and knowledge in the Yukon Territory. University of Nebraska Press

Dasgupta P, Serageldin I (2000) Social capital: a multifaceted perspective. The International Bank for Reconstruction and Development, Washington, D.C., p 424

Downing TE, Patwardhan A (2004) Assessing vulnerability for climate adaptation. In: Lim B, SpangerSiegfried E (eds) Adaptation policy frameworks for climate change: developing strategies, policies and measures. Cambridge University Press, Cambridge, pp 67-89

Eriksen SH, O'Brien K (2007) Vulnerability, poverty and the need for sustainable adaptation measures. Climate Policy 7:337-352

Feit HA (1987) North American native hunting and management of moose populations. Swedish Wildl Res Suppl 1:25-41

Ford JD (2009) Vulnerability of Inuit food systems to food insecurity as a consequence of climate change: a case study from Igloolik, Nunavut. Reg Environ Chang 9:83-100

Ford JD, Smit B, Wandel J (2006) Vulnerability to climate change in the Arctic: a case study from Arctic Bay, Canada. Glob Environ Chang 16:145-160

Ford JD, Pearce T, Smit B, Wandel J, Allurut M, Shappa K, Ittusujurat H, Qrunnut K (2007) Reducing vulnerability to climate change in the arctic: the case of Nunavut. Canda, Arctic, 60

Fukuyama F (2003) Social Capital and Civil Society. In: Ostrom E, Ahn TK (eds) Foundations of social capital. Edward Elgar Publishing, Northampton, pp 291-308

Glantz MH (1988) Societal responses to climate change: forecasting by analogy. Westview Press 
Gunderson LH, Holling CS (2002) Panarchy: understanding transformations in human and natural systems. Island, Washington, D.C., p 507

Handmer JW, Dovers S, Downing TE (1999) Societal vulnerability to climate change and variability. Mitig Adapt Strateg Glob Chang 4:267-281

Hartmann B, Wendler G (2005) The significance of the 1976 Pacific climate shift in the climatology of Alaska. Journal of Climate 18(22):4824-4839

Haycox S (2002) Frigid embrace: politics, economics and environment. Oregan State University Press, Corvallis

Holling CS (1978) Adaptive environmental assessment and management. Wiley, Chichester

IISD, IUCN, SEI (2003) Livelihoods and Climate Change:Combining disaster risk reduction, natural resource management and climate change adaptation in a new approach to the reduction of vulnerability and poverty. 34. Winnipeg, Manitoba CANADA: International Institute for Sustainable Development

Lee KN (1999) Appraising adaptive management. Conserv Ecol 3

Lemkuhl-Bodony K (2008) Fall of 2008 Seasonal Conditions in Galena, AK, edited by S. M. McNeeley, Boulder, $\mathrm{CO}$

Luers AL (2005) The surface of vulnerability: an analytical framework for examining environmental change. Glob Environ Chang 15:214-223

March JG (1994) A primer on decision making: how decisions happen. The Free, New York

McNeeley SM (2009) Seasons out of balance: climate change impacts, vulnerability, and sustainable adaptation in Interior Alaska, Ph.D. Dissertation. In Department of Anthropology, 240. Fairbanks: University of Alaska Fairbanks

McNeeley SM, Shulski MD (2011) Anatomy of a closing window: vulnerability to changing seasonality in Interior Alaska. Glob Environ Chang 21(2):464-473

Mowry T (2007) Warm temperatures make for Harder Moose hunting. Fairbanks Daily News-Miner: Fairbanks, Alaska

Nadasdy P (2003) Hunters and bureaucrats: power, knowledge, and aboriginal-state relations in the southwest Yukon. UBC, Vancouver

Nelson RK (1983) Make prayers to the Raven: a Koyukon view of the northern forest. University of Chicago Press, Chicago

Nelson RK, Mautner KH, Bane GR (1982) Tracks in the wildland: a portrayal of Koyukon and Nunamiut Subsistence. University of Alaska, Fairbanks, p 465

Nuttall M (2005) Ch. 12 hunting, herding, fishing and gathering: indigenous peoples and renewable resource use in the Arctic. In: Arctic Climate Impact Assessment. Cambridge University Press, pp 649-690

O'Brien K, Leichenko R (2008) Human security, vulnerability and sustainable adaptation. In: Human Development Report 2007/2008 - Fighting Climate Change: Human Solidarity in a Divided World. United Nations Development Program

Ostrom E, Ahn TK (2003) Foundations of social capital. Edward Elgar Publishing, Northampton, p 590

Plous S (1993) The psychology of judgment and decision making. McGraw-Hill Inc., New York

Rappaport RA (1978) Maladaptation in Social Systems. In: Friedman J, Rowlands MJ (eds) The evolution of social systems. University of Pittsburgh Press, Pittsburgh, pp 49-87

Redman C (1999) Human impacts on ancient environments. University of Arizona Press, Tuscon

Redman CL, James SR, Fish PR, Rogers JD (2004) The archeology of global change: the impact of humans on their environment. Smithosonian Books, Washington, D.C., p 292

Schneider WS (1986) On the Back Slough: Ethnohistory of Interior Alaska. In: Aigner JS, Guthrie RD, Guthrie ML, Nelson RK, Schneider WS, Thorson RM (eds) Interior Alaska: a journey through time. The Alaska Geographic Society, Anchorage, pp 147-194

Schwartz CC, Hundertmark KJ (1993) Reproductive Characteristics of Alaskan Moose, J Wildlife Manage, 454-468

Schwartz CC (1997) Reproduction, Natality, and Growth. In: Franzmann AW, Schwartz CC (eds) Ecology and management of the north American moose. University of Colorado Press, Boulder, pp 141-171

Shulski M, Wendler G (2007) The climate of Alaska. University of Alaska Press, Fairbanks

Sillitoe P (1998) The development of indigenous knowledge: a new applied anthropology. Curr Anthropol 39:223-252

Smit B, Wandel J (2006) Adaptation, adaptive capacity, and vulnerability. Glob Environ Chang 16:282-292

Smit B, Burton I, Klein RJT, Wandel J (2000) An anatomy of adaptation to climate change and variability. Clim Chang 45:223-251

Smithers J, Smit B (1997) Human adaptation to climate variability and change. Glob Environ Chang 7:129146

Thomas DSG, Twyman C (2005) Equity and justice in climate change adaptation amongst resourcedependant societies. Glob Environ Chang 15:115-124 
U.S. Fish and Wildlife Service \& U.S. Bureau of Land Management (2005) Record of Decision: March 1-5, 2005 Antlerless moose Hunting Season on Federal Public Lands in Unit 21D and Southern Unit 24. 22. Galena, Alaska

Van Ballenberghe V, Miquelle DG (1993) Mating in moose: timing, behavior, and male access patterns. Can J Zool 71:1687-1690

Vucetich JA, Peterson RO (2008) Ecological studies of wolves on Isle Royale Annual Report 2007-2008. 20. Houghton, Michigan: School of Forest Resources and Environmental Science, Michigan Technological University.

Walsh JE (2009) A comparison of arctic and antarctic climate change, present and future. Antarc Sci 110

Wheeler P (1992) Subsistence economies and the use of fish and game resources in Grayling, Anvik, Shageluk, and Holy Cross. Tanana Chiefs Conference, Inc, Fairbanks, p 173

Wolfe RJ (2000) Subsistence in Alaska: a year 2000 update. ed. Alaska Department of Fish and Game Division of Subsistence, 4 